\title{
A note on the crustal structure of the eastern Mediterranean
}

\author{
P. E. Cominakis - B. C. Papazachos $\left(^{*}\right)$
}

Received on April 30 th, 1976

SUMMARY. - $A$ simple model is proposed for the moan crustal structure of the eastern Mediterrancan. Aceording to this model, which fits the available seismic data, the crust of the eastern Vediterranean consists of five lagers of $21 \mathrm{~km}$ total thickness and the velocity of the longitudinal waves varies between 2.2 and $6.6 \mathrm{~km} / \mathrm{sec}$ in this crust.

Rrassunto. - Si propone un modello semplice relativo alla struttura della crosta in corrispondenza del Mare Mediterraneo orientale. Secondo questo modello, che si arlatta ai dati sismici disponibili, la erosta sotto il Mar . Mediteraneo orientale è formata da 5 strati con uno spessore totale di $21 \mathrm{~km}$, e la velocita delle onde longitudinali, in questa parte di crosta, varia frat 2.2 e $6.6 \mathrm{~km} / \mathrm{sec}$.

\section{IXTRODUCTION}

The eastern Menliterranean ocmpies the depression which is included between the southern Eurasian coast (Turkey - Greece), the northern African coast, the Calabrian are (Calabria - Sicily - Atlas) and the coast of Iebanon.

Although consiclerable geophysical work has been carried out in the eastern Merliterranean, especially in the last ten years or so, the opinions as to its tectonic history is still very controversial. One of Greece.

(*) National Observatery of Athens. Seismological Institute, Athens, 
the reasons for this is the fact that our knowlerge in regard to the rleep structure of this area are not very clear.

The available information concerning the cleep structure come mainly from reflection, refraction, surface waves clispersion, and gravity measurements. None of these techniques has been extensively applied to study the crustal structure of the eastern Merliterranean, but all these techniques have been used to get some information about this structure in several places of the area.

The crustal structure of the eastern Mediterranean is probably much complicated. Therefore with the available data we cannot arrive at detailed conclusions as to this structure. We believe, however, that by synthesizing properly the available greophysical results we can get a rough irlea, at least, about the mean crustal structure of this area.

In this paper an attempt is made to suggrest a crustal morlel for the eastern Mediteranean, which consists of horizontal homogeneous layers and which best fits the avalable results of the application of the reflection, refraction and the surface waves dispersion methods.

\section{1. - $A$ MODEL BASED ON THE AYAILABLE INFORMATION}

There have been published several results of the application of the reflection, of the refraction and of the dispersion of the surface waves methods, in the eastern Mediterranean. There is agreement between some of these results which concern certain parts of the crust but there are other parts of the crust for which no agreement exists. For this reason the final arlopter morlel is a result of somehow weighting the information given by each methorl according to the depth of the crustal layers.

For the shallow layers the information coming mainly from the application of the reflection methor is used. For the intermediate rrustal layers the morlel is mainly based on information roming from the application of the refraction methods. For the lower crust and just below it the results of the refraction and dispersion of surface waves methork have been used to make the morlel.

The thickness of the unconsolidated serliments has been determined in several places of the eastern Mediterranean $(3,4,5,6,11)$.

From all these determinations a mean value equal to $0.7 \mathrm{~km}$ with a standard reviation equal to $\pm 0.5 \mathrm{~km}$ has been calculated. 
The mean compressional velocity has been found equal to $2.2 \mathrm{~km} / \mathrm{sec}$, with a standard deviation equal to $+0.3 \mathrm{~km} / \mathrm{sec}$.

Under the unconsolidated sediments, material with compressional velocities between about 3 and $4 \mathrm{~km} / \mathrm{sec}$ have been observed in several places of the eastern Mediterranean $\left({ }^{4,5}\right)$. The available values have given an average thickness equal to $4.6 \pm 4.0 \mathrm{~km}$ and an average compressional velocity $3.7 \pm 0.3 \mathrm{~km} / \mathrm{sec}$ where $\pm 4.0 \mathrm{~km}$ and \pm 0.3 $\mathrm{km} / \mathrm{sec}$ are the standard reviations.

Beneath the material with average compressional velocity equal to $3.7 \mathrm{~km} / \mathrm{sec}$ a layer with velocities between about 4.1 and $5.5 \mathrm{~km} / \mathrm{sec}$ has been detected by the refraction methorl $(1,2,3,4,5)$ and has been considered to interprete surface waves dispersion data $(7,8,9)$. We have used all this information to find average values equal to $4.4 \pm 2.3 \mathrm{~km}$ and $4.8 \pm 0.5 \mathrm{~km} / \mathrm{sec}$ for the thickness of this layer and the compressional velocity, respectively.

There is weak evidence that material with compressional velocities of the order of $6.0-6.1 \mathrm{~km} / \mathrm{sec}$ exists in the central and eastern part of the eastern Mediterranean (2,6). There is, however, rather strong evirlence that such material exists under the Ionian basin (4.10). By the use of all the publisherl values an average equal to about $3 \mathrm{~km}$ has been found for the thickness of this layer. These velocities are typical of crystalline rocks.

Since the existence or non-existence of a crystalline layer in the eastern Mediterranean is of decisive importance for any theory regarding its tectonic history and the available information as to this layer is controversial, further refraction and other work is necessary to solve this basic problem.

Information for the simatic part of the erust (basaltic layer) in the eastern Merliterranean has been based on refraction measurements $(1,5)$, and on measurements of phase and grom velocities of surface seismic waves $(\overline{7}, 8,9)$. The available values give an average equal to $8.7 \pm 2.2 \mathrm{~km}$ for the thickness of this layer and an average equal to $6.6 \pm 0.2 \mathrm{~km} / \mathrm{sec}$ for the corresponding eompressional velocity.

Just under the crust the mean compressional velocity is equal to $8.1 \pm 0.1 \mathrm{~km} / \mathrm{sec}$.

Figure 1 shows schematically a simple crustal morlel of the eastern Mediterranean based on the above mentioned information. It consists of live homogeneous and horizontal layers, excluding the water layer. The mean thickness of each layer and the mean velocity of the compressional waves in each layer are shown. The total rustal thickness 


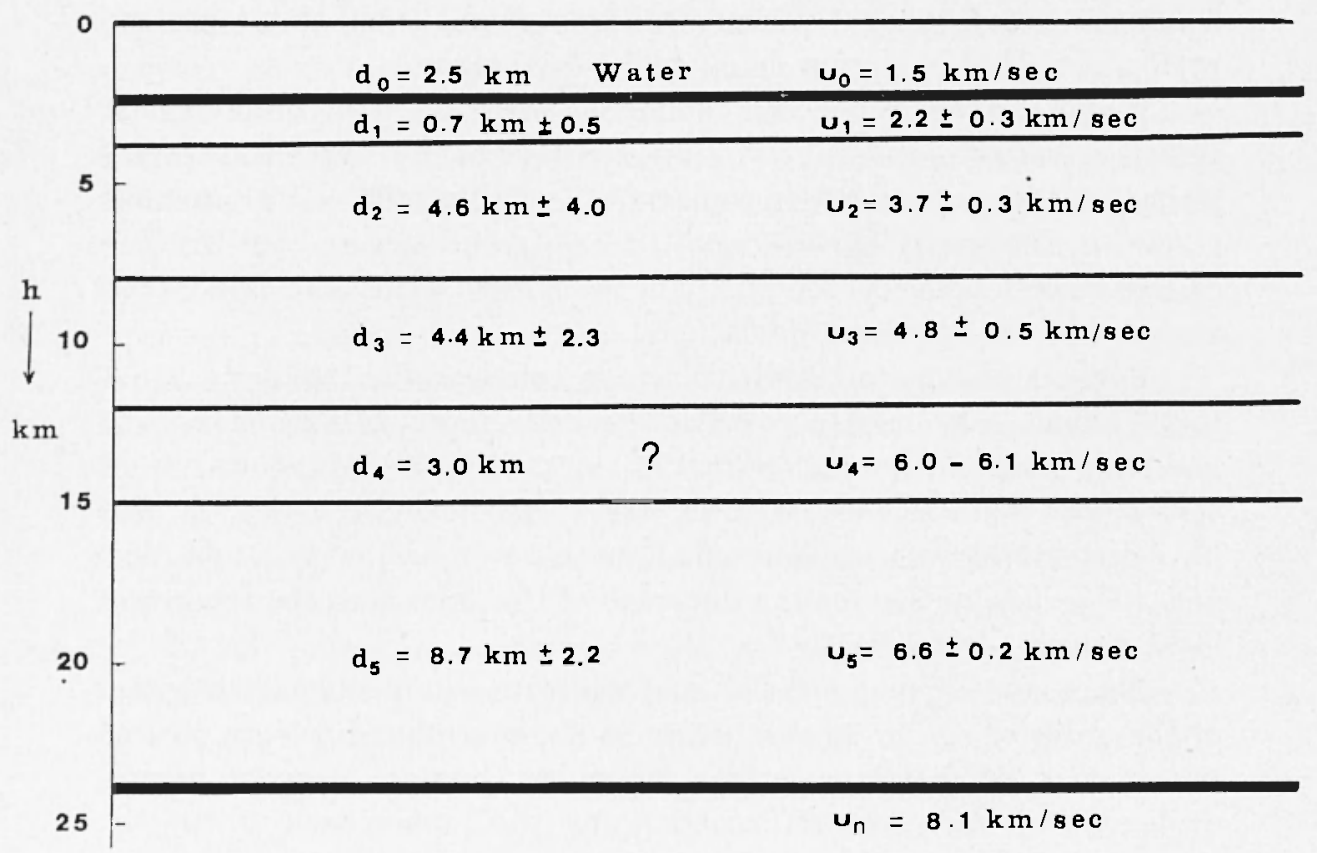

Fig. 1 - A model of the mean crustal strueture of the castern Moditerrancan Soal.

in this morlel is equal to $21.4 \mathrm{~km}$. It is understood that the crustal morlel of figure 1 is a fust rough approximation of the real crustal structure in the eastern Mediterramean.

\section{CONCLCSTONS}

The erustal structure in the eastern Merliteranean is neither typical oceanic nor typical continental. The available information permit to get a rough irlea only about the mean structure of this area.

The published seismic results can be interpreted by a morlel which consists of five horizontal and homogeneous layers with mean thicknesses equal to $0.7 \mathrm{~km}, 4.6 \mathrm{~km}, 4.4 \mathrm{~km}, 3.0 \mathrm{~km}, 8.7 \mathrm{~km}$ and corresponding compressional velocities equal to $2.2 \mathrm{~km} / \mathrm{sec}, 3.7 \mathrm{~km} / \mathrm{sec}$, $4.8 \mathrm{~km} / \mathrm{sec}, 6.0-6.1 \mathrm{~km} / \mathrm{sec}, 6.6 \mathrm{~km} / \mathrm{sec}$, but the existence of the layer with $6.0-6.1 \mathrm{~km} / \mathrm{sec}$ velocity is doubtfull at least in the eastern part of the areat. 


\section{REFEREN('ES}

(1) Ewixt .J. I., and Ewixa M., 1959. - Seismic - Refraction .Measurements in the Allantic Basins, in the Mediterranean sea, on the Mid-Allantio Ridge and in the Norwegian Sea. "Geol. Soc. Am. Bull.", 70, pp. 291-318.

(2) Finetti I., Moreidi C., 1973. - Geophysical Explomalion of the Eastern Mediterranean Sea. "Bollet di Geofis. 'Teor. ed Appl.", XV. pp. 262-341.

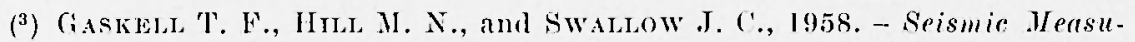
rements Wade by II. X. S. Challenger in the Allantic, I'acifir and Indian. Ocern and in the Medilerranean Sea, 1950-53. "Roy. Soc. T.ondon, Phil. 'Trans.", A251, M!. 28-83.

(1) IIxz K., 1974. - Resulls of Seismir Refraction and Seismie Reflection Ieasurements in the Ionian. Sea. "Geol. Jb.", IIannover, E2, $24 \mathrm{Abh}$., pl). 33-65.

${ }^{5}$ ) LonT .I. M., Lanoxo W. Q., and Gisar F., 1974. - Preliminary Seismic Studies in the Easlern . Medilerranean, "Ealth and Planctary Letters", 21. pp. 355-366.

$\left.{ }^{6}\right)$ Moskatenko V. N., I966. - New Data on the Structure of the Sedimentary strala and Basement in the Levant Sea. "Occanology", 6, pp. 828-836.

(i) Papazacios B. C., 1969. - Phase Telocilies of Rayleigh Haves in Southeastern Europe and Eastern IIedilerranean Sea. "Pure and Appl. Geophys.", 75, pp. 47-55.

$\left.{ }^{8}\right)$ PAYo G., 1967. - Crustal Strueture of the Wedilerranean Sea by Surface Waves, Prarl I, Group Velocily. "Bull. Seismol. Soc. Am.", 57, pp. 151172.

$\left.{ }^{9}\right)$ Paro (.., 1969. - Crustal Struchure of the Merliterranean Sea. Part II, Phase Felocily and Trarel Times, "Bull. Seismol. Soc. Am.", 59. pp. 23.42.

(10) Wences W., and IIsz K., 1970, - Preliminary Resulls of Seismic Measurements in the Ionian Sea and on the Malta Shelf. Paper Presented XIIe Assemble Générale de la Commission Seismologique Européene. Laxembourg 21-29 Sept.

(11) Wowa II., Zarunski F. F. K., I969. - Thirlieness of Cnconsolidated sediments in the Eastern Iedtiteranean Sea. "Gool. Soce. Am. Bull.", 80, pu. 2011-2614. 